\title{
The swan chariot of a solar deity: Greek narratives and prehistoric iconography
}

\author{
Tomislav Bilić \\ Archaeological museum in Zagreb, Zagreb, CR \\ tbilic@amz.hr
}

\begin{abstract}
Literary testimonies for the Greek concept of Apollo's swan chariot and the accompanying set of ideas were often discussed alongside some comparable Central and North European iconographic representations. This study approaches the problem by collating, with a help of structural analysis, a number of highly specific complex prehistoric iconographic arrangements (most notably the Dupljaja chariot), which suggest a similar concept was indeed current in the tradition of some European pre-literate societies. The principles employed here in the iconographic analysis of complex symbolic structures, offered a sound methodological basis for comparing literary with iconographic sources. It is concluded that their underlying muthos represents an account of the annual solar movement in terms of anthropomorphic causation.
\end{abstract}

IZVLEČEK - Pisni viri, ki se nanašajo na grški koncept Apolonovega voza z labodi in na idejne nastavke, ki spremljajo ta koncept, se pogosto uporabljajo ob primerljivih ikonografskih upodobitvah iz srednje in severne Evrope. V tej študiji se spoprimemo s tem konceptom s pomočjo strukturalne analize, tako da primerjamo nekaj zelo specifičnih in kompleksnih prazgodovinskih ikonografskih postavitev (najbolj znan je voz iz Dupljaja), ki kažejo na to, da je bil koncept sočasno navzoč tudi $v$ tradicijah nekaterih evropskih pred-pismenih družbah. S principi ikonografske analize kompleksnih simbolnih struktur smo postavili dobro metodološko bazo za primerjavo pisnih in ikonografskih virov podatkov. Sklepamo, da osnovni muthos predstavlja razlago o letnem gibanju Sonca v antropomorfnem smislu.

KEY WORDS - water-birds; Apollo; iconographic analysis; Dupljaja; sun

\section{Introduction}

Much has been written in the past on the question of the connections between Greek Apollo and a Central and/or Northern European prehistoric solar deity recognised in iconographic representations 1 , frequently called, not without some justification - although only if this name is put inside quotation marks and understood as a provisional term referring to a specific concept - 'Hyperborean Apollo' (Krappe 1942; 1943; 1947; Sprockhoff 1954; Gelling, Ellis Davidson 1972; Ahl 1982; Kaul 1998. 253; Kristiansen, Larsson 2005.44)2. These connections cannot be treated - and they are in general not treated in such a way - discriminatively towards other influences on the formation of this

1 For the derivation of a (hypothetical) North European anthropomorphic solar deity from an (equally hypothetical) Central European one, see Kaul $(1998.56,252)$.

2 The earliest undoubted identifications of Apollo with the sun in Greece appear in Telesilla (fr. 2 PMG) and in Aeschylus' Bassa$r a i$, where it is attributed to the Orphics (TGrF III.138 Radt ap.[Eratosth.] Cat. 24, $c f$. $\Sigma$ Germ. 273 p. 84.6-12 Breysig $=P E G r$ 1148 T I Bernabé; West 1990.38-39; Seaford 2005.602); it is also implied in Aesch. Sept. 856-860. West (1990.40-41) associates the information in the Bassarai with the description of Orpheus' katabasis in Plutarch's De sera num. vind. 22.566BC (Orph. fr. 294 Kern = PEGr 412 F, 998 T I Bernabé) involving Apollo, and concludes that Aeschylus and Plutarch might have used the same source, the Orphic poem Krater attributed to the early Pythagorean Zophyrus or, alternatively, an early Orphic-Pythagorean Katabasis (cf. Seaford 2005.602). Thus the identification of Apollo with the sun was current at the latest in the $6^{\text {th }}$ century BC. 
Olympian deity, even though they occasionally tend to be over-emphasised. Although I will not discuss numerous further components involved in Apollo's formation, I must clearly state that this essay, although focused on a single aspect, is not irreconcilable with, and fully acknowledges the existence of, other approaches (see Graf 2008; cf. Solomon 1994; Detienne 1998). The prevalent opinion among modern scholars is indeed that Apollo is a complex figure that developed diachronically by a process of synthesis, and that his 'fully formed' character can be analysed into its component parts (Burkert 1985. 144; Versnel 1985-1986.136; 1994.293; West 2007. 148 ). The results of these modern studies show that any connection with either Central or Northern Europe is at best secondary, but not irrelevant.

Two types of evidence are normally adduced in the discussions on the 'Hyperborean Apollo' (here covering both Greek, where the name is attested in literary sources, and prehistoric concepts): literary sources, when analysing Greek tradition, and the archaeological record, when analysing the prehistoric. But a coherent methodological basis for certain far-reaching conclusions has rarely been offered. This paper will try to review the available evidence, both literary and iconographic (the explananda), and to propose, building from this evidence, what I believe is a sound methodological foundation for the comparative (i.e. paradigmatic) approach in analysing the objects of material culture alongside literary testimonies, based on a structural analysis of complex iconographic arrangements, as well as to offer an interpretation of both types of evidence based on the conclusions derived from these comparisons (for the indispensability of the comparative method in religious studies, see especially Segal 2001).

The main criterion employed in the process of collating iconographic testimonies for this particular concept will be a syntagmatic analysis of their design, but one which is intimately connected to the comparative approach outlined above. This procedure was selected in order to emphasise that it was the data themselves that instigated the discussion on methodology, rather than a preconceived no- tion subsequently applied to the two categories of testimonies. However, interplay between theory and data is necessary in all research, and I will often work my way downwards, interpreting data with the help of a theory, in its turn based on ancient literary and iconographic testimonies - thus employing a form of hermeneutic circle. The main hazard of this approach is the possible fall into circular reasoning, which I will try to avoid by different control mechanisms that will be elaborated at appropriate places.

Another difference from earlier studies using similar approaches is that I have chosen to study a more restricted range of iconographic motifs, effecting a significantly more focused analysis of a single, yet complex, iconographic design. I believe that this method offers additional stability on rather slippery ground, and I am confident that the decisive element in this particular design - namely, the presence of anthropomorphic agent - offers still more evidence for the basic similarity of approaches in the treatment of identical phenomena by different traditions.

As a final introductory remark it should be emphasised that the concept analysed here was either directly or indirectly connected with cultic activities, which is discernible from both the iconographic and later literary sources, and could thus be classified as 'religious'. But, as will become clear in my discussion, the subject of analysis of this essay are literary and iconographic manifestations of a myth understood as a narrative model representing a specific aspect of physical reality (annual solar movement) 3 , which can only anachronistically be classified as a 'religious' phenomenon (see Insoll 2004. $6-8$ ). Therefore, this study will support the notion that although myth undoubtedly has much in common with the category of 'belief systems', its independence from the concept of religion or cult, with which it is connected and intertwined, but from which it is certainly distinct, should be respected 4 . This also accounts for the relative stability of the narrative model, as opposed to its appropriation by various belief-systems, which undoubtedly in the process re-interpreted it in their idiosyncratic, now largely hard to reconstruct, manners.

\footnotetext{
3 This definition of myth is very close to Donald's $(1991.213-215,259)$. He understands myth as a use of language in constructing conceptual models of the human universe, i.e. of relevant features of the environment, which creates a coherent system of explanatory metaphors. Furthermore, myth is a modelling device primarily on a thematic level, rather than episodic, focused on deriving general principles, which corresponds to the nature of the concept treated in this paper. For myth and archaeology see Insoll (2004.127-131).

4 For an overview of theories on myth in general and Greek myth in particular, see, for example, Kirk (1974), Dundes (1984), Bremmer (1988), Edmunds (1990), Graf (1993) and Csapo (2005).
} 


\section{A concise review of literary sources}

The 'Hyperborean Apollo' is mentioned for the first time by Alcaeus (born $c .620 \mathrm{BC}$ ), unfortunately only in a summary preserved by the $4^{\text {th }}$ century $\mathrm{AD}$ rhetorician Himerius5. Here, Apollo's swan-chariot in which the god flew after his birth to the land of the Hyperboreans, whence he returned to Delphi in the middle of summer, is described (Alc. fr. 307c Lobel-Page ap. Him. Or. 48.10-11) ${ }^{6}$. Unfortunately, this testimony is more often than not the single statement adduced in the discussion of the Greek concept of Apollo's swan chariot and his voyage to the Hyperboreans.

However, there are many more. First, I shall briefly review the tradition of Apollo's visit to Hyperborea. Thus, the mythic $6^{\text {th }}$ century BC sage Abaris allegedly wrote a poem on the arrival of Apollo to the Hyperboreans (Suid. $\alpha$ 18), Hecataeus of Abdera (late $4^{\text {th-early }} 3^{\text {rd }}$ century BC) described the island Helixoia in the far north inhabited by the Hyperboreans, visited every 19 years by Apollo (FGrHist 264F7; D. S. 2.47.1, 6; F11a; St. Byz. s.v. Helixoia, cf. Hdn. Gr. iii.1.281.13-14 Lentz), while Apollonius Rhodius ( 1 st half of the $3^{\text {rd }}$ century $\mathrm{BC}$ ) reports how Apollo travelled to Hyperborea starting off from Lycia (A. R. 2.674-675), and he describes Apollo's sojourn in Hyperborea as a kind of exile, not as a regular occurrence (A. R. 4.611- 617). Simmias of Rhodes (late $4^{\text {th }}$-early $3^{\text {rd }}$ century BC), on the other hand, implies he visited the Hyperboreans starting off from Babylon (fr. 2 Powell ap. Ant. Lib. Met. $20)$. Plutarch (2nd half of the $1^{\text {st }}$-early $2^{\text {nd }}$ century AD) says Apollo is absent from Delphi during the three winter months, not explicitly mentioning where he actually departs to, while for the remaining three quarters of the year the god is in his sanctuary (De E 9.389BC), and Cicero (1st century BC) reported how, according to tradition, Apollo came to Delphi from the land of the Hyperboreans (Nat. D. 3.57). Claudian (late $4^{\text {th }}$ century AD) described how Apollo leaves Delphi for Hyperborea only to return from the Riphaean on a chariot drawn by griffins (Cons. Hon. 26-27, 30-31). It seems that Claudian replaced Apollo's swans with griffins, because the latter became in time associated with Scythia and the farthest north - their fight over gold with the Arimaspians in the vicinity of Hyperborea was repeatedly describ- ed - and thus became a symbol of Apollo. Claudian certainly knew of Alcaeus' poem, as did his slightly older contemporary Himerius, or at least of a tradition that described Apollo's arrival (or return) from Hyperborea on a chariot drawn by some mythic animals. Moreover, he is the only author apart from Alcaeus who combined these two concepts, i.e. the chariot and the Hyperboreans.

The second concept, that of the swan chariot, was mentioned only occasionally by Greek authors. Thus Sappho (late $7^{\text {th-early }} 6^{\text {th }}$ century BC) and Pindar (late $6^{\text {th }}-1^{\text {st }}$ half of the $5^{\text {th }}$ century BC) deck Apollo with golden hair and lyre and 'send him drawn by swans (kuknois epochon) to Mount Helikon' (Sapph. fr. 208 Lobel-Page and Pi. fr. 262b Bowra ap. Him. Or. 46.6, trans. Campbell 1982)7. This translation suggests that Apollo used a chariot drawn by swans (cf. Page 1955.249), but epochon means 'mounted upon something', whether a horse or a chariot (LSJ s.v.); on the other hand, it is not probable that the god was carried on more than a single swan, and his swan-chariot seems to explain the passage in a satisfactory manner. Finally, Nonnus (late $4^{\text {th }}$-early $5^{\text {th }}$ century $\mathrm{AD}$ ) reported that Apollo has a winged swan, not a running horse, presumably drawing his chariot, or he has it simply to ride on (D. 38.206).

In short, this whole concept as known from literary sources seems to echo a conflation of two different yet complementary ideas: a seasonal change associated with the sun's return from the south where it abided during winter months, and its cohabitation with the Hyperboreans in the farthest north at the time of the summer solstice (Olmsted 1994.137; Bilić 2012.509-510, 515-519, 527; cf. Gernet 1981 [1933].116; Parker 2005.417-418).

\section{Hyacinthus - a convergence of literary and ico- nographic testimonies}

Interestingly, there is only a single - and rather late - iconographic depiction of Apollo in a swan-drawn chariot: the deity (with a quiver) is thus represented together with Cyrene (?) on a Roman-period engraved gem (M.-A. Zagdoun in LIMC VI.1 (1992). 169 s.v. Kyrene, no. 18). Moreover, this is the only nonEtruscan depiction of a swan-drawn chariot that can be associated with the god. The connection of this

\footnotetext{
5 Here the word Hyperborean is put inside quotation marks, because it refers to a Greek notion of Apollo associated with certain set of ideas (swans, Hyperboreans, northern voyage, etc.), not all of which were consistently attached to him in every specific manifestation of this model.

6 Aristophanes' description of swans on the Hebrus greeting Apollo (Ar. Av. 769-783) could be associated with his return from the north (Sprockhoff 1954.70; Kothe 1970.205), but this is only hypothetical.

7 Cf. fr. 52c Snell = Pa. 3 in P0xy. 5.841 and Snell's discussion in his edition of Pindar (Snell 1964.20).
} 
unusual chariot with Apollo in Etruscan tradition is plausibly established through the appearance of Hyacinthus in a chariot drawn by swans. Apollo is indeed sometimes explicitly syncretised with Hyacinthus (Plb. 8.28.2; Nonn. D. 11.220), perhaps also in iconography (L. Villard, F. Villard in LIMC V.1 (1990).550, s.v. Hyakinthos, no. 55), his Laconian appearance as Apollo tetracheir (Hsch. $\kappa 3853, c f$. к 4558; Sosib. FGrHist 595F25; Lib. Or. 11.204; IG V.1.259) can be associated with the hero (Farnell 1907.127, 371), while Spartan Hyacinthia were devoted to both (Pettersson 1992.9-41; Graf 2008.34), also suggesting a sort of syncretism. With this in mind, Hyacinthus' appearance in a swan-drawn chariot closely associates him with Apollo.

However, as opposed to Apollo in a swan chariot, this concept is almost exclusively known through iconographic representations. Actually, Philostratus ( $3^{\text {rd }}$ century $\left.\mathrm{AD}\right)$ is the only literary source mentioning the hero riding in Apollo's swan-chariot (Im. 14), albeit while describing a painting, although not the depiction itself, whereas the theme was rather popular in Etruscan art from the $4^{\text {th }}$ century BC onwards (L. Villard, F. Villard in LIMC V.1 1990.548549 s.v. Hyakinthos, nos. 35, 37-40) ${ }^{8}$. Thus the Hyacinthus/swan-chariot association is almost exclusively known through iconographic representations of Etruscan origin. This is not so strange if we take into account that Etruscan iconography occasionally illustrates certain poorly documented versions of Greek myths (Nielsen 2002. 183).

On the other hand, it will be shown below that it is perhaps possible to associate this particular Etruscan iconographic motif with a strong local prehistoric tradition of producing structurally similar complex symbolic iconographic nexuses.

\section{Archaeological evidence}

\section{Introduction}

In this part of the paper, I offer an analysis of several prehistoric iconographic arrangements reveal- ing a similar syntagmatic structure, allowing for certain paradigmatic shifts: an anthropomorphic deity (or mythic person) riding in a chariot drawn (or accompanied) by water birds, normally swans, decorated with postulated solar symbols 9 . With respect to these, it appears that often the scholars discussing many of the complex symbolic objects analysed here independently arrived at some rudimentary form of the interpretation that is argued for in this essay, but failed to precisely define the characteristics of the symbolic structure that was the object of their immediate study, to use comparative pieces of evidence and to contextualise particular manifestations of the concept underlying them in their proper intellectual setting. I will henceforth refer to this set of ideas as the 'Dupljaja concept', not because I believe it is the 'origin' of all other attestations of this matrix, but because it is its best known and, as it will be shown below, one of its most revealing, materialisation. This complex arrangement permits, I believe, the supposition of a similar underlying muthos, a story or concept shared by these complex schemes 10 .

In any case, as will be shown below, it seems more profitable to compare systems composed of several elements that otherwise appear separately, since single motifs or symbols can cover a wide range of meanings, but their arrangement into a presumably coherent structure - i.e. one that carries some meaning ( $c f$. Renfrew 1994.53) - significantly reduces the number of possible meanings. Because of this, I have selected a highly complex and specific system rather than such simpler matrices as Vogelsonnenbarke or Vogelbarke or water-bird symbolism in general, on which most of the earlier analyses focused. In this way, I hope to bypass some of the pitfalls of comparative method, especially circularity, i.e. arbitrarily adducing the meaning of a motif and applying this interpretation to other occurrences of this motif without further discussion.

I have applied two main criteria for selecting the complex sets discussed in this study. First, following Colin Renfrew, I employ a cross-cultural identifica-

8 No. 39 might show a trace of a quiver, which is highly conjectural, but it would associate the figure with Apollo, rather than Hyacinthus.

9 The postulated solar symbolism must naturally always remain tentative. As a rule, I have noted under this category only those iconographic elements that were accepted as having some solar connotations by previous authors that discussed the respective objects considered here. An element of circular argument is unavoidable at this point, but the structural analysis should eliminate the arbitrariness of the assumptions adduced here. For solar symbols in the European BA iconography, see Müller-Karpe (1978-1979.23).

10 I will use the transliterated Greek word when referring to this specific meaning of the concept 'myth' in order to avoid the negative connotations acquired by the latter, especially with respect to its truth-value. It also recollects the Aristotelian meaning of the term (Poet. 1450a4-5, cf. 32-33, 36-39), which is very close to this specific meaning. 
tion of various representations of recurring mythic persons, defined by their specific attributes (Renfrew 1994.53) ${ }^{11}$, although I have studied these 'clues' in the context of the structure of a complete iconographic scheme ${ }^{\mathbf{1 2}}$. I have thus been able to recognise a recurring interrelation of a group of motifs and their syntagmatic arrangement (an anthropomorphic deity/mythic person riding in a chariot drawn/accompanied by water birds, normally swans, decorated with postulated solar symbols), and have provided a syntagmatic analysis (cf. Hodder 1987. 3 ) of thus collated complex prehistoric iconographic arrangements (Tab. 1). This criterion could provisionally be called 'structural'.

Additionally, I have placed one of the accents on the precise (as much as possible) chronological relations in order to contextualise the discussed symbolic structures and thus to eliminate the inherent ahistorical nature of the structuralist approach ${ }^{13}$. It could be objected that the complex figures analysed in this paper cover vast chronological (more) and spatial (less) distances; this is indeed true, but I hope that the following discussion will explain why this is not an insurmountable problem 14 . The key concept with respect to this possible objection will be the definition of a large-scale context or shared cultural space in which these complex figures appear. In a similar fashion, Svend Hansen argued for a spatially and temporally broad perspective in studying the formal similarities of Neolithic and Chalcolitic anthropomorphic figurines of the Near East, Anatolia and South-Eastern and Central Europe (Hansen 2001.38-42). This criterion could provisionally be called 'contextual'.

These main criteria, together with their refinement, which allows a stronger focus and control, create a solid framework that eliminates up to a reasonable point the possibility of arbitrariness in the selection of the complex symbolic objects used in this study.

\section{Dupljaja}

Apollo's swan chariot and its connection with Hyperborea were long ago, and still regularly are, associated with the famous BA wagon model from Dupljaja (Fig. 1). It shows a male god 15 riding in what is best described as a swan-chariot, defined by three water birds emerging from the vehicle. The base of the hemispherical wagon-box is decorated with a four-spoked wheel, most probably a solar symbol (Petrović 1928-1930; Kossack 1954.11-12; Sprockhoff 1954.67; Bošković 1959; Letica 1973.63-64; Coles, Harding 1979.408; Pare 1987.58-61, Fig. 25; 1989.84-85, Fig. 4; 2004.357-358, Fig. 2; Green 1991.45, 84, 114, Figs. 88a-b; Kaul 1998.254; Harding 2000.167, 322, 324; Vasić, Vasić 2003.158160; 2003-2004.182-183; Holenweger 2011.223-

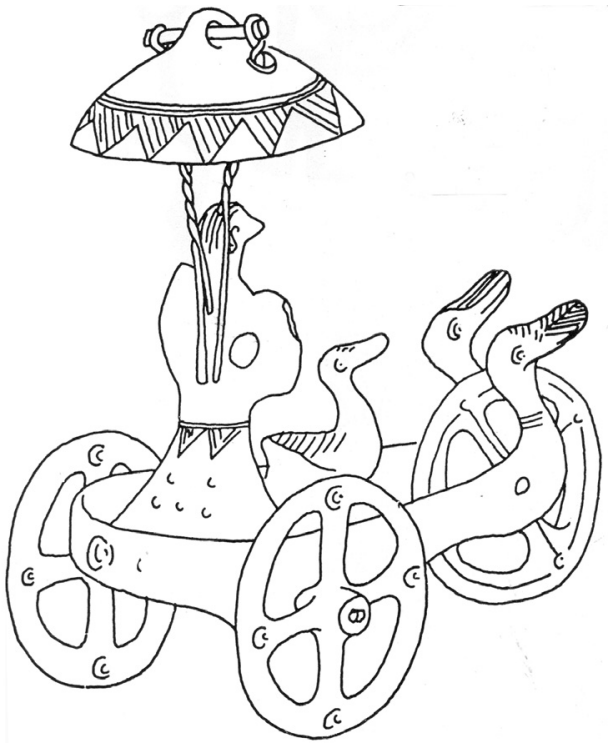

Fig. 1. Dupljaja model (after Bošković 1959.P1. 24. 13).

11 The emphasis on the anthropomorphic character of the main agent in the structure of a complex figure will be explained later; it is not conditioned by Renfrew's discussion.

12 Occasionally, an individual religious or iconographic motif could be tentatively treated as an element in a complex religious phenomenon, and, moreover, as representing some feature of particular natural forces (Kaul 1998.13). I decided not to apply this hypothesis in my discussion, since I wanted to give additional stability to my argument by relying on structural analogies between complex symbolic structures.

13 For an analysis of the ahistorical nature of structuralism, see Vidal-Naquet $(1981.175-176,185)$ and Hodder, Hutson $(2003$. 62-63). For structuralism and history, see also Harkin $(2009.39-40,44,46-48,50,52)$. For the importance of chronological relations in approaching similar issues, see Kaul $(1998.10,15)$. For the structural analysis of material culture, see Hodder (1987.3) and Hodder, Hutson (2003.45-74, 126, 214-215).

14 Compare Müller-Karpe's study on BA objects with religious symbolism, which covers the area from Egypt to Atlantic and the North Sea during the Middle and Late BA (Müller-Karpe 1978-1979).

15 An anthropomorphic solar deity, according to Sprockhoff (1954.67 (cf. Maraszek 1997.75)), Gelling, Ellis Davidson (1972.119), Green (1991.114, cf. 13, 84), Kaul (1998.254) and Kristiansen, Larsson (2005.150, 307). Holenweger (2011.223-224, 242-244) also argues for the statuette's role in the solar cult manifested in the ceramic material of the Dubovac-Žuto Brdo-Gârla Mare cultural group. For this particular solar cult (cf. Palincas 2013.317). 


\begin{tabular}{|c|c|c|c|c|c|}
\hline & Dupljaja & Knossos & Floth & Italy? & Veii \\
\hline Date (BC) & $1500-1200$ (?) & $950-900$ & $900-700$ & $1200-900$ & $900-875$ \\
\hline $\begin{array}{l}\text { Agent } \\
\text { (anthropomorphic) }\end{array}$ & male divinity & female divinity & $\begin{array}{l}\text { male divinity/ } \\
\text { divinities }\end{array}$ & $\begin{array}{l}\text { divinity/divinities } \\
\text { (male and female) }\end{array}$ & male divinity \\
\hline Transport & chariot & chariot & boat(s) & boat(s) & boat \\
\hline Water birds & $\begin{array}{c}\text { water birds + } \\
\text { ornitomorphic face }\end{array}$ & birds & water birds & water birds & water birds \\
\hline \multirow[t]{2}{*}{$\begin{array}{l}\text { Postulated solar } \\
\text { associations }\end{array}$} & $\begin{array}{c}\text { four-spoked } \\
\text { wheel }\end{array}$ & $\begin{array}{l}\text { seasonal } \\
\text { character }\end{array}$ & circles, disks & disks, circles & disks \\
\hline & Campania & Bisenzio & Cerveteri & Saône & Kriegerwagenfibeln \\
\hline Date (BC) & $850-750$ & $725-675$ & $625-600$ & $500-400$ & late $6^{\text {th }}-5^{\text {th }} c$. \\
\hline $\begin{array}{l}\text { Agent } \\
\text { (anthropomorphic) }\end{array}$ & $\begin{array}{c}\text { female (?) } \\
\text { divinity }\end{array}$ & $\begin{array}{l}\text { female (?) } \\
\text { divinity }\end{array}$ & male divinity & male divinity & male figure \\
\hline Transport & boat & boat & chariot & chariot & chariot \\
\hline Water birds & water birds & water birds & $\begin{array}{l}\text { ornithomorphic } \\
\text { body }\end{array}$ & bird's head, bird & (water) bird \\
\hline $\begin{array}{l}\text { Postulated solar } \\
\text { associations }\end{array}$ & $\begin{array}{c}\text { spirals, radiating } \\
\text { and concentric circles, } \\
\text { disks, cross }\end{array}$ & disk & rosettes & none & none \\
\hline
\end{tabular}

Tab. 1. Structural analysis of iconographic complexes discussed in the text.

224, 242-244, 334-335). Alternatively, the model can be interpreted as a sun-ship with swan-stems (Sandars 1968.174; Kaul 1998.254). This paradigmatic shift does not change much in the model's syntagmatic arrangement (cf. Kaul 1998.254). In any case, the model could be interpreted as a fairly faithful illustration of the myth of Apollo riding in a swan-chariot (although I must emphasise that it most certainly is not such an illustration) 16 .

Fortunately, it is possible to date the model with a precision that allows it to be contextualised with some certainty. It is thus regularly associated with MBA 'Danubian' anthropomorphic figurines ${ }^{17}$, and is accordingly dated to this period ${ }^{18}$. However, the Dupljaja chariot shows some features that are quite unique in the complex of the 'Danubian' MBA anthropomorphic figurines, at the same time clearly foreshadowing the future Urnfield solar/water bird symbolism (cf. Kristiansen, Larsson 2005.307-308). This fact is reflected in the attempts to date it by a number of scholars, opting for a somewhat later period (the LBA) in comparison to the opinions adduced above19. From a semantic point of view, that is; with respect to the interpretation of its meaning, however, it is less relevant whether the chariot should be dated to the Middle or Late BA, as long as its large-scale context is clearly defined: the symbolism of either a nascent or already established Urnfield cultural complex. Relatively numerous finds of a type of Kesselwagen (cauldron-wagons) incorporating the water-bird symbolism in their design 20 and other

16 Compare Sprockhoff (1954.70-71) and, more cautiously, Kaul (1998.254); this is one of the reasons that led Vasić (1954) to pronounce it a forgery.

17 For a lengthy review of previous scholarship on the origin of these figurines, see Holenweger $(2011.123-148,150-151)$; for their Aegean origin, see Holenweger (2011.45-46, 148-153, 188-191, 266-267, 270), Chicideanu-Sandor, Chicideanu (1990.69-73), Kalogeropoulos (2007.263-265) and Palincaş (2012.24); for their Central European origin, see Letica (1973.53 (cf. Kossack 1954. 9)), Sandars $(1968.176,315)$ and Kiss $(2007.125-128)$.

$18 \mathrm{Br}$ C1-Br C2, contemporaneous with LH IIIA (late 15th-14th century) Mycenaean Phi idols (Pare 1989.84; cf. Chicideanu-Sandor, Chicideanu 1990.57); Bz B (1600-1500 BC; Letica 1973.60); the whole complex of these figurines is dated to $\mathrm{Br} \mathrm{C} 1-\mathrm{Br}$ C2 (1500-1300 BC; Majnarić-Pandžić 1982.53); to Br B1-Ha A1 (1600/1500-1200/1100 BC; Kiss 2007.127), or to a somewhat broader chronological horizon (the entire MBA) (Hänsel, Hänsel 1997b.59).

19 Bz D (early Urnfield, 1300-1200 BC; Sprockhoff 1954.67, 73; Bouzek 1985.53, 178, 234; Kaul 1998.254); vague attribution to 'the Urnfield sphere', at the same time suggesting a date as late as $1050 \mathrm{BC}$ or even later (Coles, Harding 1979.408; cf. Green 1991.147); late MBA/early Urnfield period (Hänsel, Hänsel 1997b.67).

20 Orăštie, Br D-Ha A, 13 th-12 th century (Demakopolou et al. 2000.260-261, 134); Skallerup, earlier period III, Br D, 13 ${ }^{\text {th }}-12^{\text {th }}$ century (Pescheck 1972.50; Egg, Kaul 2001.474, Abb. 55); Peckatel, earlier period III, Br D, 13 $3^{\text {th }} 12^{\text {th }}$ century (Demakopolou et al. 2000.261); Acholshausen, transition from Ha A2 to B1, c. 1050/1020 BC (Pescheck 1972.49-52); the 8th-7th century examples from Bujoru (Moscalu, Beda 1991.217, Abb. 11), Delphi (Kilian-Dirlmeier 1974), Marsiliana d'Albegna (Egg 1991.192-207), Veji, Grotta Gramiccia (Müller-Karpe 1974.96-97, T. 22.1), and Vetulonia, Circolo dei Lebeti (Egg 1991.202 Abb. 10). 
objects decorated with motifs such as water birds, sun-symbols, and (occasionally) a barque (especially the Vogelsonnenbarke), dating from the Bronze-age Urnfield cultural complex and the later Hallstatt period $^{21}$, distributed throughout the Central Europe and beyond (Italy, Northern Europe, the Aegean), show that the Dupljaja wagon, although unique in its complexity, is not an isolated find, but part of an elaborate and widely distributed set of beliefs.

Thus the existence of an intricate concept can be recognised in the Middle Danube region in the second half of the $2^{\text {nd }}$ millennium $\mathrm{BC}$, manifesting itself in the Dupljaja figure. This complex structure then occasionally reappears in succeeding periods throughout Central, South-Eastern, South-Central and Northern Europe, as will become apparent in the following discussion.

\section{Northern Europe}

The only direct Northern European structural parallel to the 'Dupljaja concept' is an LBA belt buckle from Floth (Ha B2/3-Ha C1, $9^{\text {th }}-8^{\text {th }}$ century) (Hänsel, Hänsel 1997a.133-134; Hänsel 1997.20-21, Fig. 2) (Fig. 2). Two symmetrical Vogelbarken with stylised human adorants (the head of one of the figures is formed of two concentric circles, the head of the other of a single circle) are depicted on this buckle, with three solar disks around them positioned at sunrise, zenith and sunset? (Hänsel 1997.21) - the two flanking ones pulled by water birds. Bernhard Hänsel recognises in the left corner of the plate another stylised human figure with the head in the form of a solar disk and argues that this depiction suggests the existence of the personification of the sun - an anthropomorphic solar deity - in the north of Europe (Hänsel 1997.21).

\section{Italy}

As already noted, the concept of Hyacinthus in a swan-chariot is exclusively known through Etruscan material. Several other examples from earlier periods similar to the 'Dupljaja concept' were found in Etruria. The earliest is a bronze Protovillanovan razor (12 1 th $^{\text {th }}$ century), unfortunately of unknown provenance (Bouzek 1985. 216, Fig. 103. 11; Kaul 1998.284-285, Fig.
180)22. The razor is in the abstract form of a female idol (a paradigmatic shift), with a double-axe depicted on the body, inside of which is a mirror-image figure with arms formed of Vogelbarken, with two flanking figures of a similar type, this time with $\mathrm{Vo}^{-}$ gelbarken forming their lower extremities - or, better, showing a human figure inside a Vogelbarke (perhaps representing 'die Personifizierung der Sonne'; Jockenhövel 1974.87) and four water birds in the corners (Fig. 3). Not unlike the Knossian pithos discussed below, this symbolism suggests an association with female cult (Bouzek 1985.217; Wachsmann 1998.195-196). In chronological terms, this object would represent a transition from the Middle or Late BA Dupljaja model to the somewhat later Italian specimens described below.

A similar representation is depicted on a vessel from Veii decorated in the Buckeltechnik and dated to the early Iron Age (early 9th century) (Fig. 4). The vessel type to which the Veii specimen belongs is attributed to the late phase of the Central European Urnfield culture (Von Merhart 1952.12-13). The decoration on this vessel depicts a frieze of water birds (swans?), but not the symmetrical Vogelbar$k e$, although one could argue that the bodies of the birds indeed form a boat. Between the heads, concentric circles are depicted, most probably designating the sun, and, most interestingly, two human figures with outstretched arms and circular heads (Sprockhoff 1954.81-82, Fig. 24; cf. von Merhart 1952.Pls. 3.8, 23.1; Iaia 2004.397, Fig. 2.10). Since both the birds and the sun-rings form a continuous frieze, it is unlikely that two human figures repre-

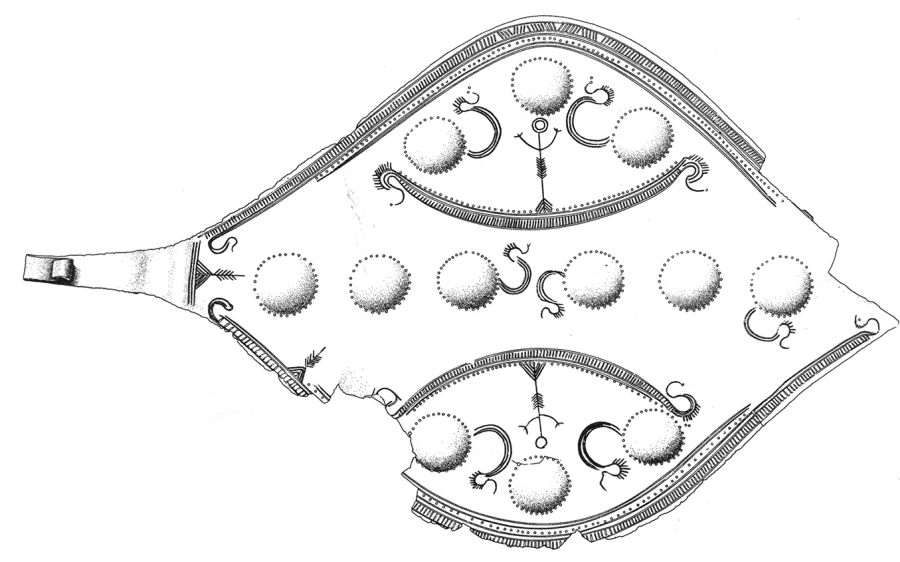

Fig. 2. Belt buckle from Floth (after Hänsel 1997.20-21, Fig. 2).

21 Bouzek (1985.178) dates the earliest Vogelbarke in early Br D (after 1250 BC), while Matthäus (1980.319) and Kaul (1998.278, $280-281,283)$ date it to the much later Ha B1 (c. $1000 \mathrm{BC})$.

22 Jockenhövel opts for a somewhat later date (10 th century) and recognises in it an eastern Mediterranean influence (Jockenh $\ddot{0}-$ vel 1974.84, 87-88; Pl. 19.1). 
sent twins of any kind (pace Sprockhoff 1954.81). Indeed, the decoration on the Veii vessel could represent a sun deity travelling in a solar swan-boat.

A slightly later group of Early IA fibulae ( $\mathrm{Ha} \mathrm{B} 3, c$. 850-750 BC) from Campania, with a person or a deity in a Vogelbarke, almost certainly belongs to the same cultural circle and represents the same matrix (see Lo Schiavo 2010.880-881, Pls. 694- 698, 883, 885-886, Pls. 709, 719-725), as does a bowl handle from Bisenzio in Etruria (late $8^{\text {th }}$ / early $7^{\text {th }}$ century) depicting a person or a deity whose hands and feet extend into ornithomorphic forms standing in a circular Vogelbarke (Kossack 1954.Pl. 13.1; Bietti Sestieri, Macnamara 2007; 2004).

Another example of a similar concept is a bucchero vase from Tomba Calabresi (?) in Cerveteri, dated to the later part of the 7th century (Guggisberg 1996. 185, Fig. 16). It is modelled in the form of a double imaginary being with horses' heads and ornithomorphic body, with two rosettes on its sides, suggesting a solar association and at the same time symbolising a wagon. A man standing on the body of the animal and holding a yoke in his hand is at the same time the rider and wagon-driver, riding his $\mathrm{Vo}^{-}$ gelpferde or being drawn by them in a chariot ( $\mathrm{Gug}$ gisberg 1996.186). The bucchero vase could represent a solar deity in his chariot drawn by mythic horse-birds.

Finally, Woytowitsch believes that a bronze $6^{\text {th }}$ century lid in the form of a large stylised bird's head (with a small bird on the top) on whose back a human figure drives a biga (the wheels are not represented, but only the wagon-box) probably originat-

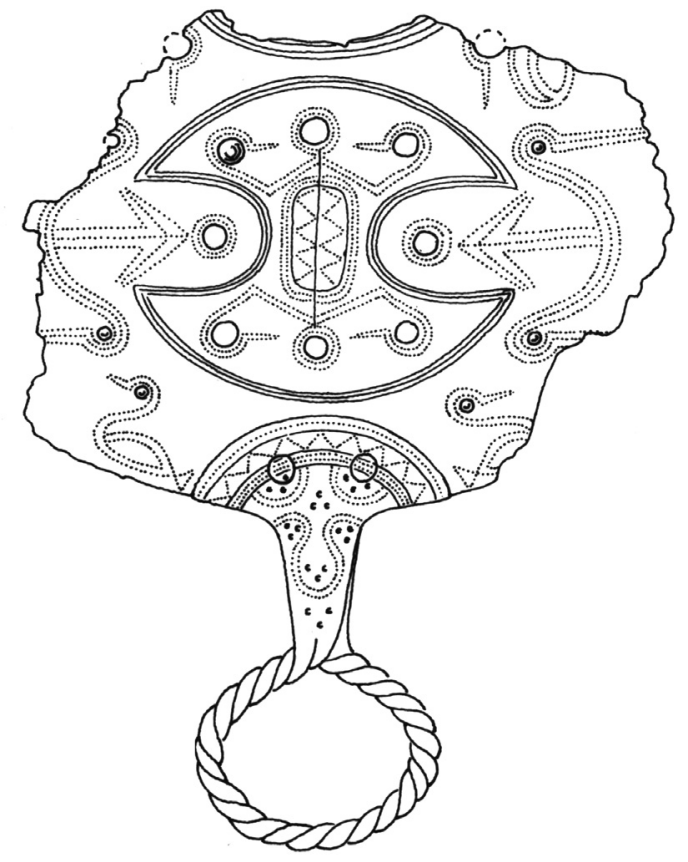

Fig. 3. Protovillanovan razor (after Jockenhövel 1974.P1. 19.1).

ed in Italy, yet it was found in the Saône River (Woytowitsch 1978.64-65, Pl.29). Thus, this depiction can be added to the Etrurian ones enumerated above.

Apparently, the 'Dupljaja concept' was current in Central Italy during both the prehistoric and historical (Etruscan) periods, with a clear continuity between the two, which supports (but does not prove) the proposed continuity with later literary testimonies argued for below.

\section{Eastern Alpine region}

The so-called Kriegerwagenfibel, a group of Iron Age fibulae with the depiction of a male figure on a

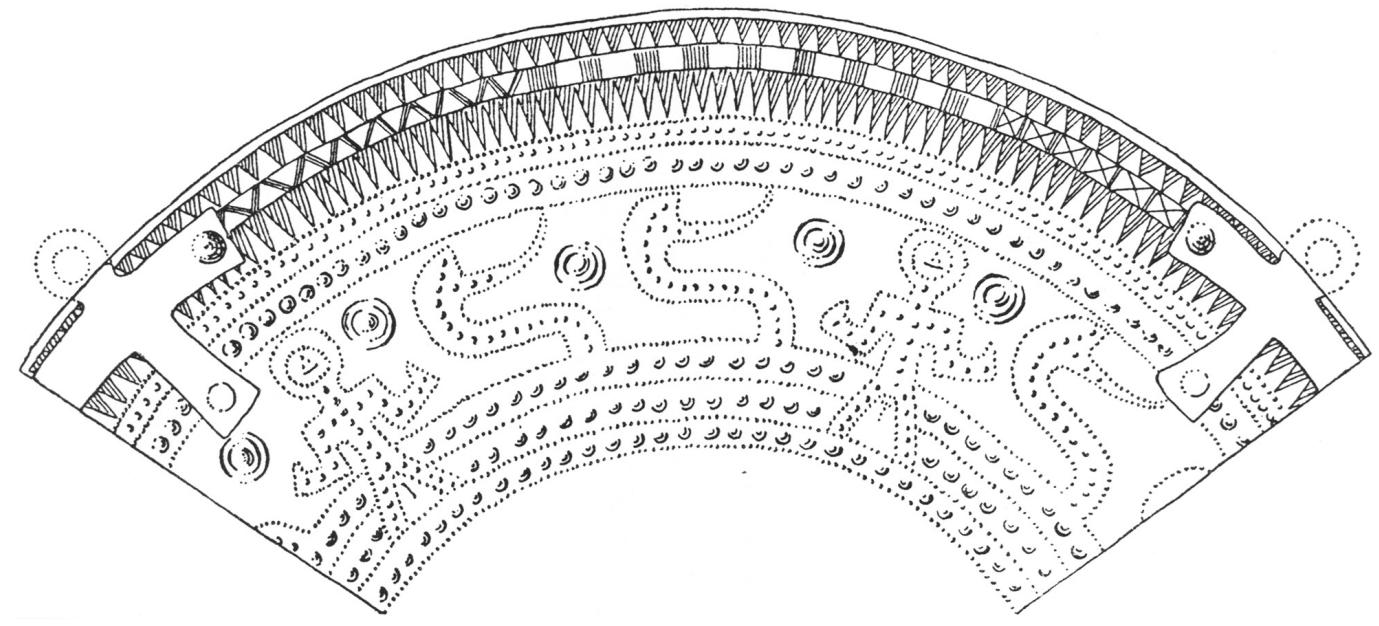

Fig. 4. Vessel from Veii (after Sprockhoff 1954.82, Fig. 24).

23 Perhaps even to the early MBA (Br B), if the specimen from Nagyhangos belongs to this type (Müller-Karpe 1978-1979.23, Abb. 6.23; 1980.Pl. 318.E8). 
horse-drawn chariot on the bow and a bird at the end of the foot, found at several sites in the eastern Alpine region (Starè 1954.188, Fig. 15; Guštin 1974.95-98; Lunz 1974.139-140, Pl. 40.9, 91B; Tecco Hvala et al. 2004.Pl. 10.A2; Tecco Hvala 2012.228, 259, 260, Fig. 99.2, 262-263), are composed of identical structural elements, and should be compared to the 'Dupljaja concept'. Regardless of the fact that there is no apparent solar symbolism in these fibulae, they were nevertheless associated with the Phaethon legend (Tecco Hvala 2012.262, 340-341, 385). Even though this seems somewhat far-fetched, their solar character could be tentatively recognised in other structural elements present in these artefacts. These fibulae are very similar and chronologically close to the bronze lid found in the Saône described above.

\section{Possible Central European parallels}

Several bronze Vogelsonnenbarke pendants found over a wide area (Hungary, Bosnia, Italy, France, Austria), and dated to a long time span stretching from the middle Urnfield 23 to the late Hallstatt period (Ha A2 to D) perhaps portray an anthropomorphic figure, with Vogelbarke representing its outstretched hands (Kossack 1954.Pls. 11.2-4, 7, 9-11, 13, 12.4, 7, 9-18; Bouzek 1985.171, Fig. 86. 12, 174, Fig. $87.1)^{24}$. At the same time, the Vogelbarke, together with the figure's circular head, could represent a transport vehicle of the solar disk. Thus this representation can at the same time be interpreted as an anthropomorphic figure with hands in the form of a Vogelbarke, or as a Vogelbarke transporting the solar disk. Due to their extreme stylisation, and, more specifically, to the uncertainty regarding the anthropomorphic interpretation of the composition, I am not completely convinced that these artefacts belong to the group of complex symbolic sets discussed above. Nevertheless, it is possible to recognise in them all the structural elements that were present in other manifestations of the 'Dupljaja concept': anthropomorphic figure, solar symbolism (the disk-shaped head of the figure), boat (explicitly present only in the specimens reproduced on Kossack's plates 11.7 and 10, otherwise suggested by the $\mathrm{Vo}^{-}$ gelbarke representing the figure's outstretched hands), and water birds. Moreover, both geographically and chronologically, they belong to the same large-scale context (the Urnfield symbolism) with other examples discussed here. Thus I would leave the question of their affiliation open, which equally applies to two Ha D pendants from Vače and Vinji Vrh in Slovenia, where a highly stylised combination of an anthropomorphic figure and a Vogelbarke can be discerned (Kossack 1954.44, Pl. 17.2, 4; Tecco Hvala 2012.298).

\section{The Aegean}

A similar nexus appears in the decoration of a straight-sided pithos from Knossos. This depiction of a winged female divinity riding in a chariot 25 with birds in her hands suggests that the 'Dupljaja concept' was current on Crete in the Protogeometric period (later $9^{\text {th }}$ century). This is the only Aegean example of a complex symbolic structure related to the 'Dupliaja concept', suggesting (but not in itself proving) continuity between the pre-literate and literary traditions in this particular region. Cretan adaptations, which can be understood as paradigmatic shifts that do not change the structure of meaning of the matrix, are revealed in the driver's gender and in the appearance of birds, which are depicted identically to earlier illustrations of that kind in Cretan tradition. The seasonal character of the depiction is evidenced in the fact that the pithos shows two contrasting scenes, probably representing summer and winter (Fig. 5) 26 . While it is not clear from the depiction whether the birds actually draw the chariot, the similarity with the 'Dupljaja concept' is more than obvious. Since this particular complex symbolic structure departs in the intensity of paradigmatic shifts from other examples studied in this paper, I am willing to accept that it might not belong to the group of manifestations of the 'Dupljaja concept'; however, this would not affect any of the main arguments expressed in this essay.

\section{Methodological procedure for comparing the literary and iconographic record}

\section{Material evidence for past beliefs}

Several important questions must be raised with respect to the categorical statements outlined in the introductory section of the part of the paper analysing material objects, which I will try to answer here, while simultaneously building an argument for the possibility of comparing literary with iconographic sources. One of the basic questions is whe-

24 Kossack $(1954.42,44,53,58-59)$ only argues for the anthropomorphic nature of the amulets reproduced on his plate 12.1-10 (cf. for analogous interpretation of similar amulets Müller-Karpe 1978-1979.26).

25 Coldstream $(1984.97,99)$ argues that the wheeled platform is an abbreviation of a chariot (cf. Marinatos 2000.126).

26 Coldstream (1984.99, Figs. 1-2) recognises in this representation the spring arrival of the goddess, and her departure in winter (cf. Marinatos 2000.126). 

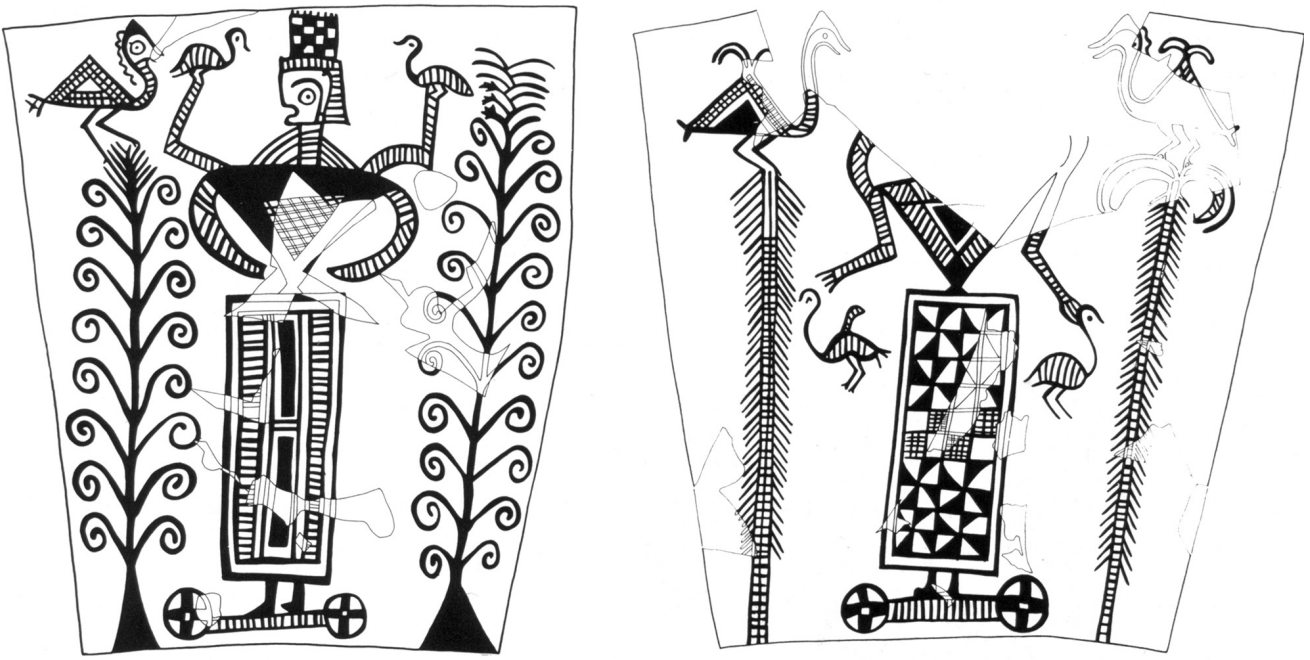

Fig. 5. Straight-sided pithos from Knossos (after Guggisberg 1996.183, Figs. 12-13).

ther it is at all possible to gain any insight into a past belief system that is manifested only in material objects. Without acknowledging this possibility, it remains impossible either to assess the content of, or meaning inherent in a system, or to compare it with literary sources. The cognitive-processual approach indeed allows that iconographic analysis, that is, the analysis of symbolic systems, represents a coherent method for reconstructing particularities and meanings of a belief system attested in non-literary sources (Renfrew 1994.49, 53-54). Thus a cautious interpretation of past beliefs based only on iconography is indeed admissible, representing an important step in attempts to compare them profitably with each other or with written testimonies.

\section{Reading the visual language}

In general, iconography can be understood as a symbolic system employing a coherent non-verbal language used for codifying a culture's reflections on objective reality through a system of associations, with the knowledge of the significance of these symbols being shared by everybody that is 'initiated' into the system (Morgan 1985.7; Renfrew 1994. 53; $c f$. Harding 2000.345-340) 27. A 'translation' of visual into spoken language, which is a basic act of any iconographic interpretation (Morgan 1985.6), is necessary in order to compare iconographic with literary testimonies. In this way, the former are treated as equals to the latter, differing idiomatically but not essentially.

\section{Structural analysis of visual language}

Acknowledging iconography as an interpretable system of communication is a first step in building a de- fensible method for comparing material and literary sources, but is also a crucial move towards allowing the introduction of a profitable structural study of complex iconographic systems, which was actually applied in the preceding discussion. Since language, as the form of its communication, is inextricably linked with meaning (cf. Hodder, Hutson 2003.160), a structural analysis of the language's visual form must necessarily be incorporated into the interpretation of meaning (Morgan 1985.0), for it is the structure of iconographic elements that reveals the meaning of a complex image, rather than individual elements taken outside their immediate context. This analysis is therefore focused on finding structural principles behind complex images - what Morgan appropriately calls an idiom (Morgan 1985.9) but what could more specifically be understood as 'the content of ideas' that assemble signs into a syntagmatic or paradigmatic set (Hodder 1987.3), and which I previously termed a muthos. The Dupljaja model is precisely this kind of a complex figure which should be studied in terms of structural analysis and compared with other analogous nexuses in order to interpret 'the semantic implications of syntax' (Morgan 1985. 16). This is exactly what I am trying to do in this essay.

\section{The transfer of meaning}

With reference to the problem of context, it is now time to analyse another important question raised in my introduction to the part of the paper analysing material objects: whether the transfers of symbols between cultures could also be accompanied with the transfers of meaning (Miličević Bradač 2005. 187), i.e. whether it is possible to argue for any type

27 On some idiomatic differences between textual and pictorial mode of representation, see Ornan (2005.11-12). 
of connections between the meaning(s) of these complex arrangements. That is, after I have recognised syntagmatic similarities in the structure of several complex prehistoric iconographic matrices, I must now raise the question of their mutual relations. Are meaningful relations between these complex figures even possible? A transfer of a symbol, however complex, bereft of its underlying meaning is not very revealing for attempting to reconstruct a past belief system, although it could be revealing in other respects. But the recognition of the existence of a shared muthos, 'story' or concept behind symbols could allow some insight into past beliefs, even without reconstructing the actual contents of the underlying tradition.

Once again, the cognitive-processual approach allows the recognition of references in iconographic representations to recurrent themes across cultures, and the existence of single coherent systems, both symbolic systems and systems of belief underlying them, where there are significant overlaps between the specific symbols that appear at various locations (Renfrew 1994.49, 53-54). In other words, the existence of shared cross-cultural belief systems is recognised in the appearance of similar iconographic solutions in different cultural systems. Consequently, under certain conditions, similar iconography could indicate similar beliefs. A concrete example of this interpretation is provided by Hansen's study of the formal uniformity of Neolithic and Chalcolitic anthropomorphic figurines, for which he argued that it indicates the existence of distinct ideas behind them, which he classified as elements of a religious beliefsystem (Hansen 2001.42-45).

A similar conclusion can be reached by a study of post-processualist or contextualist accounts of diffusion, which are implicitly discussed in the foregoing cognitive-processual account of recurrent cross-cultural iconography 28. Ian Hodder and Scott Hutson thus argue that objects can be transferred from culture to culture or context to context with their meaning unchanged, or if changed, this new meaning is still based on the old (Hodder, Hutson 2003.140) 29. Thus, once again, under certain conditions, similar objects could indicate similar beliefs. However, a 'larger-scale context in which similar meanings are assigned to similar objects' must be defined in order to be able to discuss the more localised contexts responsible for both spatial and temporal variability, if any exists, in various manifestations of both widespread and long-term symbolic structure I have recognised and discussed in this paper (Hodder 1990. 21; cf. Miličević Bradač 2005.188). I have indeed tried to summarily contextualise (i.e. to position them chronologically and culturally) individual manifestations of the symbolic structure discussed in this paper, which I provisionally called the 'Dupljaja concept', at appropriate points in the discussion, and also to provide a particular large-scale context in which this structure appeared and in which similar sets could have had related meanings ( $c f$. Hodder 1987.8). I believe I have managed to avoid circularity in my reasoning - defining a large-scale context by the successive appearances of a similar structure and then interpreting the structure by its participation in that very context - by delineating this large-scale context (when discussing the Dupljaja model) by additional elements that it contains: the Urnfield symbolism. In any case, the existence of the particular symbolic complex (or cultural koine) to which the 'Dupljaja concept' belongs is non-controversial, and does not in any way depend on its delineation as outlined in this paper (see, e.g., Bouzek 1985). This large-scale context will be further discussed in the concluding section of this essay.

\section{The transfer of beliefs}

This archaeological large-scale context corresponds to what Graf refers to as an osmotic similarity of cultural space, in which a transfer of analogous ritual and mythic concepts between cultures is as likely an explanation for their formation as is independent origin (Graf 2004a.5). Here the emphasis is on the transfer of concepts or beliefs (i.e. muthoi), rather than objects, but it is equally plausible to assume that muthoi accompanying iconography with cultic significance are transmitted in a precisely identical fashion, especially in light of the discussion in the preceding section of this paper. Thus both narratives and symbolic representations - the latter together with accompanying beliefs - are equally transferrable between cultures, which allows attempt at reconstructing these very beliefs through a comparison with literary sources.

28 I find it a felicitous occurrence that two different approaches to archaeological theory agree on this particular point, although this does not automatically prove its validity. For their respective positions on religion, here used as a broad term encompassing symbolism and belief, see Insoll (2004.79-87, 94-100); for Hodder's position specifically, see Bredholt Christensen, Warburton (2014).

29 Here the authors do not refer to complex symbolic structures, but their observations certainly apply to these even more than on simpler objects. 
Transferability is indeed one of the most conspicuous characteristic of traditional stories or myths (Bremmer 1994.57; cf. 2011.540; Wyatt 2005[2001].170), and both motifs and entire narratives can migrate between cultures, including their denotative applications (Burkert 1988.12; Graf 2004b.52). In any case, these borrowings between cultures are never random, but rather result from a structural similarity between myths in both the 'receiving' and 'giving' culture (Doniger 2009.208). Thus a transfer of beliefs - whether accompanied by or accompanying iconographic solution with cultic significance or not - is plausibly ascertained; moreover, it is myths or traditional stories that are particularly prone to diffusion. But other types of 'beliefs' are also culturally transcendent. Thus the transmission of scientific 'traditions' between cultures is an accepted fact in the history of science. Knowledge or methods (the contents of the 'tradition') are received, adapted and occasionally transformed when being translated between cultures, but they still remain within the culturally transcendent tradition (Rochberg 1992.549550). This fact is tangentially relevant to the contents of the narrative model discussed in this essay, since the particular muthos reconstructed here attempts to give an account of a phenomenon that would later be treated by Greek cosmologists and astronomers, although in a radically different fashion.

With respect to the relation between material testimonies and narratives that treat identical concepts, the former are sometimes indeed of prime importance in studying the latter. The significance of iconography in recognising oral tradition behind it is emphasised by Walter Burkert, who argues that iconographic treatments of myths "... play a fundamental role in the fixation, propagation and transmission of those myths ..." (Burkert 1988.25). He further maintains that iconography can unmistakably indicate connections between different societies, although at the same time he believes it cannot positively indicate a particular myth's diffusion (Burkert 1988.26). He allows for some transfer of underlying meaning, but also recognises possible deviations (Burkert 1988.27). These well-balanced remarks, equally applicable to a pre-literate period (but without the control offered by literary sources), emphasise that one should always have in mind possible misunderstandings and reinterpretations in the transmission of meanings of symbolic representations; the method I have adopted in this paper, in the first place the focus on a quite specific single, yet complex, iconographic design, of a particular character (i.e. anthropomorphism), is meant to reduce these pitfalls as much as possible, although they can never be completely evaded.

It is possible to raise the objection here that religion is a structured system whose elements derive their meaning through their relations with other elements on various levels, from the arrangement of elements in a nexus to the complete world-view of a society. Change on any of these levels affects all the others, and the meanings of apparently identical elements also change in new circumstances (Sourvinou-Inwood 1995.20-24, 29)30. Indeed, even collective representations of the physical environment are argued to be culturally determined, and thus both these representations and their meanings are liable to alterations, which are induced by changes in other elements of the systems forming a society's worldview (Sourvinou-Inwood 1995.22-23). But I have demonstrated that meanings can be preserved within a common cultural space, and I will show immediately below that this is especially the case when complex symbolic structures are involved. This claim is less dogmatic and allows for both modification and preservation of meaning, without a priori rejecting, but insisting on arguing for or against either possibility. Moreover, a preservation of meaning does not mean that, for example, the 'Dupljaja concept' was not modified in a number of ways - which are particularly visible in paradigmatic shifts noted at appropriate points - but that both elements (less) and nexuses (more) can keep their meaning relatively unchanged; what is more, these meanings can be reconstructed by following a careful methodological procedure.

All the manifestations of the 'Dupljaja concept' analysed here are, naturally, culturally determined, but even so they have a stable referent in the physical environment. The precise roles of these manifestations in the world-views or belief-systems of their respective societies, however, are much harder to grasp, and I have not attempted to reconstruct them here (see Kaul 1998; Kristiansen, Larsson 2005). This is thus not a simple case of dynamism vs. apparent permanency, but rather of dogmatism vs. argued tolerance. My case should be judged by assessing the arguments for continuity of ideas and their expression in material form I have offered and

30 Paradoxically, in the same work, Sourvinou-Inwood (1995.19-20, 25, 29) does acknowledge continuity in certain elements of various religious nexuses, although not the nexuses themselves. 
not by an a priori rejection due to some presupposed eternal flux in the content of ideas forming beliefsystems. Two additional arguments could be adduced in further support of my position: the inherent conservatism in ancient religious works of art (Ornan 2005.10) and the more conservative nature of cultural forms in earlier periods (Wyatt 2005[2003]. 220 ). Both these factors speak in favour of preservation of meaning in the concrete transfer of complex symbolic structures argued for here.

\section{Transfer of complex symbolic structures}

It is important to emphasise that, on one hand, a simpler form of a symbol makes its interpretation to the 'uninitiated' more difficult (Morgan 1985. 7; Miličević Bradač 2005.188-189) and thus more complicated to transmit unchanged and unscathed its intrinsic meaning between cultures, but on the other hand, "... complex symbolic structures are more likely to maintain their internal meaning unchanged than simpler ones, as their transmission demands the adoption of a corresponding complex knowledge ... the parallel transmission of two or more symbolic structures makes it increasingly likely that they maintained their internal meaning unchanged, as it testifies to a more complex and direct transmission of knowledge ..." (Kristiansen, Larsson 2005.22).

This statement is an important argument for the comparison between symbolic structures attempted here. It plausibly suggests that a complex structure in this case a matrix consisting of a travelling solar deity or, if one prefers, an anthropomorphic agent providing causation of solar movement - might have been transmitted from one cultural complex to another without losing much of its intrinsic meaning. In this sense, it is not unreasonable to presume that certain ideas were transmitted both horizontally (in spatial terms) and vertically (in temporal). Since the meaning of complex symbolic structures is more likely to be transmitted unchanged between cultures, it can be argued that the ideas (muthoi) behind them were transmitted together with their manifestations in iconographic arrangements.

\section{The Dupljaja model as a complex symbolic structure accompanied by a muthos}

It is possible to recognise in the Dupljaja model an iconographic depiction of a mythic concept that could have played - to paraphrase Burkert - an im- portant role in the latter's fixation, propagation and transmission. Generally, this is hardly a novel conclusion, since a number of earlier authors recognised its importance, although not in such a specific sense as argued for in this paper. Thus the origin of the concept of a solar chariot or boat associated with swans was traced to Central Europe, from where it arrived in both Greece and Northern Europe (Sprockhoff 1954.60, 71-73, 103; Gelling, Ellis Davidson 1972.119; Ahl 1982. 39; Kaul 1998.53, 55-56, 75, 93-94, 130-136, 143-148, 157-163, 173-178, $214-215,242-244,251-258,260-261,276-278$, 282-284). The Dupljaja model itself is described as a vital link in this process (Sprockhoff 1954.73; Gelling, Ellis Davidson 1972.119; Hänsel, Hänsel 1997b.67; Kaul 1998.253, 256). But what is novel in this essay is that, while the authors named above all discussed a more general concept (solar chariot/boat associated with water birds), I have taken into account and emphasised the anthropomorphic nature of the main agent in the iconography 31 . While theirs is a legitimate hypothesis, it nevertheless seems safer to draw conclusions from an even more complex and less ambiguous example such as the one chosen for this discussion. What is more, this symbolic structure was selected precisely for its complexity and specificity, which permitted a more secure 'control' over speculating on various possible semantic interpretations of 'mute' artefacts of material culture in order to, finally, allow the comparison of the content of ideas behind these material objects with literary sources.

\section{Comparison of literary sources with iconog- raphy}

This discussion finally raises the all-important question: can the muthos - in the meaning of an applied traditional tale, a narrative model representing a specific aspect of physical reality - behind prehistoric iconography be compared to the one attested in literary sources? The foregoing discussion demonstrate, I believe, that a positive answer can be plausibly defended, or at least that it is possible to (1) gain insight into a past belief system manifested only in material objects, (2) translate the visual language of iconography into a spoken idiom by (3) performing a structural analysis of complex iconographic symbolic sets in order to enable the interpretation of their meaning, and (4) recognise the transmission of both the meaning and beliefs accompanying symbolic structures between cultures shar-

31 Kaul (1998.251-256) does discuss the anthropomorphic solar deity in this context, but not in the specific way I am studying it in this paper. 
ing a common cultural space, (5) especially when these symbolic structures are complex. With this in mind, it certainly seems possible to compare the written mutho $i$ with those reconstructed in steps (1) to (5).

Several parallel case studies might further strengthen the argument. Thus Stuart Thorne postulated a similar hypothesis of iconographic and narrative continuity in the case of the concept of Cretan Zeus. He recognises that a story or myth of Zeus' birth was 'firmly associated' with a constant iconography - a youthful god - first attested in the Minoan period (Thorne 2000.149-152). The similarity between my thesis and Thorne's lies in the fact that the early attestations of the youthful god iconography are not accompanied by literary evidence, but the interpretation of iconography both in this early and later periods is associated with literary evidence accompanying the latter 32 . Nevertheless, both solely iconographic and iconographic and narrative continuities are emphasised in Thorne's paper, persistently re-appearing or being preserved in differing spatial, temporal and cultural frameworks. This is exactly parallel to my interpretation of the 'Dupljaja concept' and its relation to literary testimonies.

In a similar fashion, Preben Sørensen interprets iconographical sources from a largely illiterate period of Nordic history with the help of myths recorded in a later period, basing his comparative method mainly on the recognition of a common cultural affiliation of iconographical and literary material, even though the sources are both spatially and temporally dispersed (Sørensen 2002 [1986].121-122, 130). Goodison likewise freely discusses iconographic sources from an illiterate period of Aegean (pre) history (which she prioritizes) alongside later literary testimonies (focusing on the earliest written works), arguing that their correspondence actually strengthens her particular claims (Goodison 1989. 119-123, 131, 23-168).

Another comparable case is Kristian Kristiansen's study of Divine Twins in Bronze Age belief-systems, whose additional value lies in that it offers a methodological framework (Kristiansen 2014; cf. Kristiansen, Larsson 2005.20-24, 256-257, 263-265, 316, 329,368 ), roughly analogous to the one employed in this essay. He argues for the complementarity of literary and archaeological sources from the Bronze Age onwards, and uses the former to formulate a hypothesis, by identifying gods and their characteristic features in textual evidence (both Bronze-Age and later), which he subsequently 'tests' in the archaeological record by identifying corresponding features in material testimonies. Kristiansen believes he has found a full correspondence between the two types of evidence in the case of Divine Twins and freely uses the archaeological record alongside literary evidence in his study of the phenomenon ( $\mathrm{Kr}$ stiansen 2014.81-82). His method is complementary to my own and, if applied to the concept discussed here, would similarly allow a comparison between the two types of evidence.

These parallel cases show that a profitable parallel study of iconography with literary sources is indeed possible, offering theories that explain a number of otherwise poorly understood phenomena.

\section{Concluding remarks: large-scale context, an- thropomorphism and the contents of the mu- thos}

Before proceeding to emphasise and clarify several key suggestions that were proposed in various parts of this essay, I must point out that it was not my intention to extensively discuss the precise genetic relations between different manifestations of the 'Dupljaja concept', since the method I have employed in this paper cannot be used for this purpose. Similarly, I cannot discuss here the complicated problem of cultural interrelations during the LBA and EIA between Central and South-Eastern Europe, although this question is certainly raised by my discussion, since its solution is similarly outside the scope of the analytic procedure I have employed in the paper. These connections are discussed throughout this essay only in the broadest terms, but I must emphasise it is generally acknowledged that they indeed existed 33 .

The analysis performed here can, on the other hand, help to recognise the proper large-scale context in which this complex symbolic figure appears. Furthermore, it can suggest its possible meaning, that is, the content of the muthos underlying its manifestations,

32 Thorne (2000.150) regards the myth/story accompanying iconography as a constant, and does not associate it with 'religious' or 'theological' interpretation, which he finds variable.

33 The literature on this subject is indeed vast, and I can only offer a selection here: Milojčić (1948-1949), Garašanin (1953; 1962; 1982; 1983), Kossack (1954), Gimbutas (1965), Gelling, Ellis Davidson (1972), Müller-Karpe (1978-1979), Coles, Harding (1979), Matthäus (1980; 1981), Bouzek (1985; 1994), Schauer (1985), Pare (1987; 1989) and Kaul (1998). 
especially when compared with relevant literary sources, which is precisely what is attempted here. Finally, the conclusions reached in this way reveal something new - or support something only scarcely known from literary sources - with respect to the Greek notion of 'Hyperborean Apollo' and its underlying concept.

Thus, in the analysis of material evidence, a largescale context of various appearances of the 'Dupljaja concept' in which the manifestations of this concept occur and in which structurally similar arrangements have related meanings was defined: it could provisionally be called the Urnfield symbolic complex, after its most distinctive manifestation. It is not easy to precisely delineate either its spatial or temporal span: it certainly encompassed the entire Balkan (with an outpost in the Aegean) and Carpathian regions, together with much of Central Europe, with an offshoot in the Nordic region, and also Italy; furthermore, it could be argued that it spans at least the full millennium from the mid-2nd to mid-1 ${ }^{\text {st }}$ millennium BC. Within this context the osmotic nature of cultural space provides an alternative model for previously dominant discourse of invasions and migrations 34 , allowing for an inter-cultural transfer of symbols, especially complex symbolic systems, together with their accompanying meanings. In this particular case, perhaps the culturally transcendent term 'tradition' should specifically be applied to what I regularly called the 'Dupljaja concept', since this term emphasises its realised transferability, longevity and propensity to expand spatially.

The Dupljaja model could be understood as a particularly important object for understanding one important part of the symbolism of this large-scale context. I have already noted that it probably had an important role in the spread of the concept of a solar chariot or boat associated with swans from Central to both Northern and Southern Europe. But more generally it could be claimed that it also played a decisive role in the formation of the Urnfield symbolic complex (Pare 1987.61; 1989.84; cf. Sandars 1968.175), and thus its importance - on a much lesser scale - in the formation of what I have called the 'Dupljaja tradition' is immediately obvious.

Next, an attempt to reconstruct the contents of the muthos behind both material evidence and literary sources seems possible at this point. In this context, the anthropomorphic nature of the agent in the complex symbolic structure of the 'Dupljaja tradition' should not be treated simply as a development of earlier, pre-anthropomorphic ideas accounting for similar phenomena. In this respect, the present analysis bears an additional weight, since it recognises a supplementary feature that reveals more information on the concept behind a group of structurally similar material testimonies. Although the question of the occurrence of anthropomorphism in myth or science and human cognition in general is a complicated and widely discussed issue, I cannot enter into an extended treatment of this topic here, and will offer instead a summary review of a relatively recent plausible thesis. Building upon the work of numerous predecessors, Guthrie recognises anthropomorphism both in religion and in science as an almost universal explanatory method, a strategy of hypothesising about the surrounding world and attempting a plausible interpretation of it (Guthrie 1993.3-4, 31-38, 62-64, 82-89, 102-103, 176, 197; Segal 2004.33). The very act of perception, he continues, is already thoroughly theoretical and interpretative and, furthermore, identical to cognition, which is the origin of the prevalence of anthropomorphism in all forms of thought (Guthrie 1993. 37, 90-98, 121, 140,188, 201-204). Thus, it seems that anthropomorphism has its place in interpretations of nature when understood as a model-building on the basis of metaphor and analogy. It is, moreover, 'uniquely intelligible' and accounts for a large number of phenomena, resulting in a truly scientific interpretation:

"They [the gods] give much explanatory return for little investment. Hypothesizing a humanlike being at work behind appearances accounts for effects of unparalleled diversity. This principle, that efficiency in explanations is the ratio of effects predicted to hypotheses made, underlies Occam's razor: do not multiply hypotheses unnecessarily" (Guthrie 1993.189).

Consequently, anthropomorphism is equally present (even if not to the same extent) in both myth and science, in this way effectively bridging a large gap that seemed to exist between these two assumed forms of thought. It thus cannot be treated as an 'improvement' on some earlier non-anthropo-

34 For the introduction of Apollo in Greece by various migration-theories, see Müller (1839.48, 219-220, 266-267, 272), Farnell (1907.99), Sprockhoff (1954.68), Kothe (1970.219-221, 223-227); for the survey of the problem of 'Dorian migration' and the Sea Peoples, see Hall (1997.4, 6-15, 64-65, 114-121, 156, 158-161) and Dickinson (2006.2-4, 11, 44-54, 77, 102, 159, 243). 
morphic thesis accounting for the same phenomenon, and should be studied in its own right. Since it is undoubtedly present in the 'Dupljaja tradition', it must be studied with respect to this tradition in the context of its explanatory qualities noted above, and not merely as one iconographic solution among many employed by those working in the tradition of the Urnfield symbolic complex. My proposed reconstruction of the contents of the muthos behind this tradition takes into account this decisive circumstance, which is further strengthened by the use of Greek literary testimonies, allowed by the procedure outlined in steps (1) to (5) above.

All the elements that appear in the structure of manifestations of the 'Dupliaja tradition' point to a close parallelism with the 'solar' myth of the Delphian Apollo: an anthropomorphic figure transported in a vehicle and decorated with solar symbols, drawn by animals with an undeniable seasonal character 35 . The annual solar movement is a time-factored phenomenon, and the only means to either describe or account for it in prehistory was through a story or muthos (Marshack 1972.133, 197, 279, 283, 316, 330; cf. Burkert 1979.23). This resulted in the creation of a narrative model representing a specific aspect of physical reality in terms of anthropomorphic causality: the annual solar movement, with an emphasis on the solstices, as observed, recognised, described and interpreted by prehistoric European populations. An anthropomorphic explanatory model, accompanied by an array of relatively stable nonanthropomorphic symbols, suggests a shared tradition accounting for a specific phenomenon, while every piece of evidence gathered either from iconographic or literary sources points to the tradition's seasonal or, more precisely, solar character. While the validity of this particular character cannot be conclusively proven due to the inherent nature of the material being studied, it best explains all the available evidence, while none contradicts it ( $c f$. Sourvinou-Inwood 1995.133-134).

Finally, Alcaeus' 'Hyperborean Apollo' - and the same could be claimed for the Greek notion of this concept in general, as attested in other authors - is thus one of the manifestations of this narrative model expressed in a hymn to a deity that was precisely in the period when Alcaeus was composing it in the process of attaining his illustrious Pan-Hellenic sta- tus. There is no basis, however, for calling the deity or mythic person attested in the archaeological record either 'Apollo' or 'Hyperborean Apollo' without the use of quotation marks. The 'Dupljaja tradition' (in the sense I outlined above), on the other hand, does indirectly suggest that Apollo could have occasionally been recognised as a sun god in Greece, with a special connection to the solstices, at least in the concepts associated with the Delphian myth discussed in the first part of the paper, although it should again be pointed out that this does not exclude numerous other functions he fulfilled in Greek society, nor does it emphasise this particular feature at the expense of others.

In conclusion, in this essay I have provided an analysis of a complex prehistoric iconographic structure which I christened the 'Dupljaja concept', consisting of an anthropomorphic solar deity riding in a chariot drawn (or accompanied) by water birds. This complex arrangement permitted the recognition of a similar underlying muthos; after reconstructing the large-scale context in which this structure appears, which is also reflected in literary testimonies, I concluded that its underlying muthos represents an account of the annual solar movement in terms of anthropomorphic causation.

35 For the birds' seasonal character specifically in the Bronze Age, see Teržan (1999.123). Cunliffe (2002.121) argued that the communities living in northern Scotland actually associated the seasonal migration of the whooper swan to the annual solar movement. 


\section{References}

Ahl F. M. 1982. Amber, Avallon, and Apollo's Singing Swan. American Journal of Philology 103(4): 373-411.

Bilić T. 2012. Apollo, Helios, and the Solstices in the Athenian, Delphian, and Delian Calendars. Numen 59: 509532.

Bietti Sestieri A. M., Macnamara E. 2007. Prehistoric Metal Artefacts from Italy (3500-720BC) in the British Museum. British Museum. London.

Bošković D. 1959. Quelques observations sur le char cultuel de Dupljaja. Archaeologia Iugoslavica 3: 41-45, pls. 21-25.

Bouzek J. 1985. The Aegean, Anatolia and Europe. Cultural Interrelations in the $2^{\text {nd }}$ Millennium B.C. Aströms. Göteborg.

1994. Late Bronze Age Greece and the Balkans: A Review of the Present Picture. Annual of the British School at Athens 89: 217-224.

Bredholt Christensen L., Warburton D. A. 2014. Ian Hod-der and the Neolithic. In L. Bredholt Christensen, 0. Hammer and D. A. Warburton (eds.), The Handbook of Religions in Ancient Europe. Routledge. Abingdon, New York: 45-52.

Bremmer J. 1988. Interpretations of Greek Mythology. Routledge. London.

1994. Greek Religion. Oxford University Press. Oxford.

2011. A Brief History of the Study of Greek Mythology. In K. Dowden, N. Livingstone (eds.), A Companion to Greek Mythology. Oxford University Press. Oxford: 527-547.

Burkert W. 1979. Structure and History in Greek Mythology and Ritual. University of California Press. Berkeley.

1985. Greek Religion. Cambridge University Press. Cambridge.

1988. Oriental and Greek Mythology: The Meeting of Parallels. In J. Bremmer (ed.), Interpretations of Greek Mythology. Routledge. London: 10-40.

Campbell D. A. 1982. Greek Lyric I. Sappho, Alcaeus. Harvard University Press. Cambridge.

Chicideanu-Sandor M., Chicideanu I. 1990. Contributions to the Study of the Gîrla Mare Anthropomorphic Statuettes. Dacia 34: 53-75.
Coldstream J. N. 1984. A Protogeometric Nature Goddess from Knossos. British Institute of Classical Studies 31: 93-104.

Coles J. M., Harding A. F. 1979. The Bronze Age in Europe. Methuen. London.

Csapo E. 2005. Theories of Mythology. Blackwell. Malden.

Cunliffe B. 2002. The Extraordinary Voyage of Pytheas the Greek. Walker. New York.

Demakopolou K., Eluere C., Jensen J., Jockenhövel A. and Mohen J.-P. 2000. Gods and Heroes of Bronze Age Europe. The Roots of Odysseus. Nationalmuseet. Copenhagen.

Detienne M. 1998. Apollon le couteau à la main. Une approche expérimentale du polythéisme grec. Gallimard. Paris.

Dickinson 0. 2006. The Aegean from Bronze Age to Iron Age. Routledge. London, New York.

Donald M. 1991. Origins of the Modern Mind. Harvard University Press. Cambridge.

Doniger W. 2009. Claude Lévi-Strauss's Theoretical and Actual Approaches to Myth. In B. Wiseman (ed.), The Cambridge Companion to Lévi-Strauss. Cambridge University Press. Cambridge: 196-215.

Dundes A. 1984. Sacred Narrative. Readings in the Theory of Myth. University of California Press. Berkeley.

Edmunds L. 1990. Approaches to Greek Myth. Johns Hopkins University Press. Baltimore.

Egg M. 1991. Ein neuer Kesselwagen aus Etrurien. Jahrbuch des Römisch-Germanischen Zentralmuseums Mainz 38: 191-220

Egg M., Kaul F. 2001. Kultwagen. In H. Beck, D. Geuenich and H. Steuer (eds.), Reallexikon der germanischen Altertumskunde, Band 17: Kleinere Götter - Landschaftsarchäologie. De Gruyter. Berlin: 463-478.

Farnell L. R. 1907. The Cults of the Greek States. Vol. 4. Clarendon Press. Oxford.

Garašanin M. 1953. Banat-srpsko Podunavlje-Kerameikos. Rad Vojvođanskih muzeja 2: 67-72.

1962. Arheološki prilozi problemu velike egejske seobe. Diadora 2: 117-234. 
1982. The Bronze Age in the Central Balkan Area. In J. Boardman, I. E. S. Edwards, N. G. L. Hammond and E. Sollberger (eds.), Cambridge Ancient History. Vol. III/ 1. Cambridge University Press. Cambridge: 163-186.

1983. Dubovačko-Žutobrdska grupa. In A. Benac (ed.), Praistorija jugoslavenskih zemalja. IV - Bronzano doba. Akademija nauka i umjetnosti Bosne i Hercegovine. Centar za balkanološka istraživanja. Sarajevo: 520-535.

Gelling P., Ellis Davidson H. 1972. The Chariot of the Sun and Other Rites and Symbols of the Northern Bronze Age. Dent. London.

Gernet L. 1981. The Anthropology of Ancient Greece. Johns Hopkins University Press. Baltimore.

Gimbutas M. 1965. Bronze Age Cultures in Central and Eastern Europe. Mouton. The Hague.

Goodison L. 1989. Death, Women and the Sun: Symbolism of Regeneration in Early Aegean Religion. University of London. London.

Graf F. 1993. Greek mythology. Johns Hopkins University Press. Baltimore.

2004a. What is Ancient Mediterranean Religion? In S. Iles Johnston (ed.), Religions of the Ancient World. A Guide. Harvard University Press. Cambridge: 3-16.

2004b. Myth. In S. Iles Johnston (ed.), Religions of the Ancient World. A Guide. Harvard University Press. Cambridge: 45-58.

2008. Apollo. Routledge. London.

Green M. 1991. The Sun-Gods of Ancient Europe. B. T. Batsford. London.

Guggisberg M. 1996. Eine Reise von Knossos nach Strettweg. Archäologischer Anzeiger 2: 175-195.

Guštin M. 1974. Gomile starejše železne dobe iz okolice Boštanja. In M. Guštin (ed.), Varia Archaeologica. Posavski muzej Brežice. Brežice: 87-119.

Guthrie S. E. 1993. Faces in the Clouds. A New Theory of Religion. Oxford University Press. New York, Oxford.

Hall J. 1997. Ethnic Identity in Greek Antiquity. Cambridge University Press. Cambridge.

Hänsel A., Hänsel B. 1997a. Gaben an die Götter - Schätze der Bronzezeit Europas. Museum für Vor- Und Frühgeschichte. Berlin. 1997b. Herrscherinsignien der älteren Urnenfelderzeit. Ein Gefäßdepot aus dem Saalegebiet Mitteldeutschlands. Acta Praehistorica et Archaeologica 29: 39-68.

Hänsel B. 1997. Gaben an die Götter - Schätze der Bronzezeit Europas - Eine Einführung. In A. Hänsel, B. Hänsel (eds.), Gaben an die Götter - Schätze der Bronzezeit Europas. Museum für Vor- und Frühgeschichte. Berlin: 1122.

Hansen S. 2001. Neolithic Sculpture. Some Remarks on an Old Problem. In P. F. Biehl, F. Bertemes (eds.), The Archaeology of Cult and Religion. Archaeolingua. Budapest: $37-52$.

Harding A. F. 2000. European Societies in the Bronze Age. Cambridge University Press. Cambridge.

Harkin M. E. 2009. Lévi-Strauss and History. In B. Wiseman (ed.), The Cambridge Companion to Lévi-Strauss. Cambridge University Press. Cambridge: 39-58.

Hodder I. 1987. The Contextual Analysis of Symbolic Meanings. In I. Hodder (ed.), The Archaeology of Contextual Meanings. Cambridge University Press. Cambridge: 1-10.

1990. The Domestication of Europe. Blackwell. Oxford.

Hodder I., Hutson S. 2003. Reading the Past. Current Approaches to Interpretation in Archaeology. Cambridge University Press. Cambridge.

Holenweger E. 2011. Die anthropomorphe Tonplastik der Mittel- und Spätbronzezeit im mittel- bis unterdanubischen Gebiet. Eine Untersuchung zu ägäischen Traditionen und ihrer Verbreitung an der unteren Donau. Unpublished PhD thesis. Saarland University. Saarbrücken.

Iaia C. 2004. Lo stile della 'barca solare ornitomorfa' nella toreutica italiana della prima età del ferro. In N. Negroni Catacchio (ed.), Preistoria e Protostoria in Etruria. Miti simboli decorazioni - ricerche e scavi. Atti del Sesto incontro di studi 1. Centro studi di preistoria e archeologia. Milano: 307-318.

Insoll T. 2004. Archaeology, Ritual, Religion. Routledge. London-New York.

Jockenhövel A. 1974. Ein reich verziertes ProtovillanovaRasiermesser. Prähistorische Bronzefunde 20(1): 8188, pls. 19-21.

Kalogeropoulos K. 2007. Miniature Clay Anthropomorphic Representations in Greece and Europe through the Late Mycenaean Period: Similarities and Differences. In I. Galanaki, H. Tomas, Y. Galanakis and R. Laffineur (eds.), Between the Aegean and Baltic Seas. Prehistory across Borders. University of Texas-Universitè de Liège. Austin, Liège: 257-266. 
Kaul F. 1998. Ships on Bronzes. A Study in Bronze Age Religion and Iconography 1. National Museum. Copenhagen.

Kilian-Dirlmeier I. 1974. Ein bronzener Kesselwagen aus Delphi. Archäologisches Korrespondenzblatt 4(4): 349352.

Kirk G. S. 1974. The Nature of Greek Myths. Penguin. London.

Kiss V. 2007. Contacts Along the Danube. A Boat Model from the Early Bronze Age. In I. Galanaki, H. Tomas, Y. Galanakis and R. Laffineur (eds.), Between the Aegean and Baltic Seas. Prehistory across Borders. University of Texas-Universitè de Liège. Austin, Liège: 119-129.

Kossack G. 1954. Studien zum Symbolgut der Urnenfelder- und Hallstattzeit Mitteleuropas. De Gruyter. Berlin.

Kothe H. 1970. Apollons ethnokultureller Herkunft. Klio 52: 205-230.

Krappe A. H. 1942. Apollôn Kuknos. Classical Philology 37(4): 353-370.

1943. Avallon. Speculum 18(3): 303-322.

1947. Apollôn Onos. Classical Philology 42(4): 223-234.

Kristiansen K. 2014. Religion and society in the Bronze Age. In L. Bredholt Christensen, O. Hammer and D. A. Warburton (eds.), The Handbook of Religions in Ancient Europe. Routledge. Abingdon, New York: 77-92.

Kristiansen K., Larsson T. B. 2005. The Rise of Bronze Age Society. Cambridge University Press. Cambridge.

Letica Z. 1973. Antropomorfne figurine Bronzanog doba u Jugoslaviji. Filozofski fakultet. Beograd.

Lo Schiavo F. 2010. Le fibule dell'Italia meridionale $e$ della Sicilia: dall'eta del bronzo recente al VI secolo a. C. 2. Prähistorische Bronzefunde 14(14). Franz Steiner Verlag. Stuttgart.

Lunz R. 1974. Studien zur End-Bronzezeit und älteren Eisenzeit im Südalpenraum. Sansoni. Firenze.

Majnarić-Pandžić N. 1982. O porijeklu srednjebrončanodobne antropomorfne plastike u jugoslavenskom Podunavlju. Opvscvla Archaeologica 7: 47-60.

Maraszek R. 1997. Kultgerät im mittleren Oderraum: Die Deichselwagen. In A. Hänsel, B. Hänsel (eds.), Gaben an die Götter - Schätze der Bronzezeit Europas. Museum für Vor- und Frühgeschichte. Berlin: 71-75.
Marinatos N. 2000. The Goddess and the Warrior. The Naked Goddess and Mistress of Animals in Early Greek Religion. Routledge. London, New York.

Marshack A. 1972. The Roots of Civilization. The Cognitive Beginnings of Man's First Art, Symbol, and Notation. McGraw-Hill. New York.

Matthäus H. 1980. Mykenische Vogelbarken. Antithetische Tierprotomen in der Kunst des östlichen Mittelmeerraumes. Archäologisches Korrespondenzblatt 10(4): 319330 .

1981. Kuknoi de êsan to arma - Spätmykenische und urnenfelderzeitliche Vogelplastik. In H. Lorenz (ed.), Studien zur Bronzezeit. Festschrift für Wilhelm Albert von Brunn. Von Zabern. Mainz: 277-297.

von Merhart G. 1952. Studien über einige Gattungen von Bronzegefäßen. Festschrift der Römisch-Germanischen Zentralmuseums in Mainz 2: 1-71, pls. 1-26.

Miličević Bradać M. 2005. The Transfer of Symbols and Meanings: The Case of the 'Horns of Consecration'. Documenta Praehistorica 32: 187-196.

Milojčić V. 1948-1949. Der Dorische Wanderung im Lichte der vorgeschichtlichen Funde. Archäologischer Anzeiger 63-64: 12-36.

Morgan L. 1985. Idea, Idiom and Iconography. In P. Darcque, J.-C. Poursat (eds.), L'iconographie minoenne. French School at Athens. Paris: 5-19.

Moscalu E., Beda C. 1991. Bujoru. Ein Grabhügel der Basarabi-Kultur mit Votivkesselwagen aus Rumänien. Prähistorische Zeitschrift 66(2): 197-218.

Müller K. 0. 1839. The History and Antiquities of the Doric Race. Murray. Oxford.

Müller-Karpe H. 1974. Der Grab 871 von Veji, Grotta Gramiccia. Prähistorische Bronzefunde 20(1): 89-97, pls. 22-28.

1978-1979. Bronzezeitliche Heilszeichen. Jahresbericht des Instituts für Vorgeschichte der Universität Frankfurt a.M.: 9-28.

1980. Handbuch der Vorgeschichte. Vol. IV/3. Beck. München.

Nielsen M. 2002. Greek Myth - Etruscan Symbol. In S. des Bouvrie (ed.), Myth and Symbol I. Symbolic Phenomena in Ancient Greek Culture. The Norwegian Institute at Athens. Bergen: 171-198.

Olmsted G. 1994. The Gods of the Celts and the IndoEuropeans. Archaeolingua. Budapest. 
Ornan T. 2005. The Triumph of the Symbol. Pictorial Representation of Deities in Mesopotamia and the Biblical Image Ban. Vandenhoeck \& Ruprecht. Göttingen.

Page D. 1955. Sappho and Alcaeus. Clarendon Press. Oxford.

Palincaş N. 2012. Investigating Bronze Age Social Organisation in the Lower Danube Region. The Case of the Žuto Brdo-Gârla Mare Area. Istros 18: 13-38.

2013. Notes on Sun Cult and Burials in the Romanian Middle and Late Bronze Age (ca 2000-1200 BC). In V. Sîrbu, R. Stefanescu (eds.), The Thracians and their Neighbors in the Bronze and Iron Ages. Proceedings of the $12^{\text {th }}$ International Congress of Thracology 2. Istros. Braşov: 311-322.

Pare C. 1987. Der Zeremonialwagen der Urnenfelderzeit: seine Entstehung, Form und Verbreitung. In F. E. Barth, J. Biel, M. Egg, A. France-Lanord, H. E. Jaochim, C. Pare, P. Schauer and H. P. Uenze (eds.), Vierrädrige Wagen der Hallstattzeit. Untersuchungen zu Geschichte und Technik. Römisch-Germanisches Zentralmuseum. Mainz: 2567.

1989. From Dupljaja to Delphi: The Ceremonial Use of Wagon in Later Prehistory. Antiquity 63: 80-100.

2004. Die Wagen der Bronzezeit in Mitteleuropa. In M. Fansa, S. Burmeister (eds.), Rad und Wagen. Der Ursprung einer Innovation Wagen im Vorderen Orient und Europa. Von Zabern. Mainz: 355-372.

Parker R. 2005. Polytheism and Society at Athens. Oxford University Press. Oxford.

Pescheck C. 1972. Ein Reicher Grabfund mit Kesselwagen aus Unterfranken. Germania 50: 29-56.

Petrović J. 1928-1930. Votivna kolica iz Dupljaje. Starinar 5: 21-28.

Pettersson M. 1992. Cults of Apollo at Sparta: The Hyakinthia, the Gymnopaidai and the Karneia. Svenska Institutet i Athen. Stockholm.

Renfrew C. 1994. The Archaeology of Religion. In C. Renfrew, E. B. W. Zubow (eds.), The Ancient Mind: Elements of Cognitive Archaeology. Cambridge University Press. Cambridge: 47-54.

Rochberg F. 1992. The Cultures of Ancient Science: Some Historical Reflections. Introduction. Isis 83(4): 547553.

Sandars N. K. 1968. Prehistoric Art in Europe. Penguin. Harmondsworth.
Schauer P. 1985. Spuren orientalischen und ägäischen Einflusses im bronzezeitlichen Nordischen Kreis. Jahrbuch des Römisch-Germanischen Zentralmuseums Mainz 32: 123-195.

Seaford R. 2005. Mystic Light in Aeschylus' Bassarai. Classical Quarterly 55: 602-606.

Segal R. A. 2001. In Defense of the Comparative Method. Numen 48(3): 339-373.

2004. Myth. A Very Short Introduction. Oxford University Press. Oxford.

Snell B. 1964. Pindari Carmina cum Fragmentis 2. Teubner. Leipzig.

Solomon J. 1994. Apollo: Origins and Influences. University of Arizona Press. Tuscon.

Sørensen P. M. 2002. Thorr's Fishing Expedition (Hymiskviđa). In P. Acker, C. Larrington (eds.), The Poetic Edda: essays on Old Norse mythology. Routledge. London-New York: 119-137.

Sourvinou-Inwood C. 1995. 'Reading' Greek Death to the End of the Classical Period. Clarendon Press. Oxford.

Sprockhoff E. 1954. Nordische Bronzezeit und frühes Griechentum. Jahrbuch des Römisch-Germanischen Zentralmuseums Mainz 1: 28-110.

Starè F. 1954. Prazgodovinske Vače. Univerza v Ljubljani. Ljubljana.

Tecco Hvala S. 2012. Magdalenska gora: družbena struktura in grobni rituali železnodobne skupnosti. Magdalenska Gora: Social Structure and Burial Rites of the Iron Age Community. Založba ZRC SAZU. Ljubljana.

Tecco Hvala S., Dular J. and Kocuvan E. 2004. Železnodobne gomile na Magdalenski gori. Eisenzeitliche Grabhügel auf der Magdalenska gora. Narodni muzej Slovenije. Ljubljana.

Teržan B. 1999. An Outline of the Urnfield Culture Period in Slovenia. Arheološki vestnik 50: 97-143.

Thorne S. 2000. Diktaian Zeus in Later Greek Tradition. In J. A. MacGillivray, J. M. Driessen and L. H. Sackett (eds.), The Palaikastro Kouros. A Minoan Chryselephantine Statuette and its Aegean Bronze Age Context. British School at Athens. London: 149-162.

Vasić M. M. 1954. Analiza dupljajskih kolica. Starinar 4(2): 376-380. 
Vasić R., Vasić V. 2003. Bronzezeitliche und eisenzeitliche Vogeldarstellungen im Zentralbalkan. Prähistorische Zeitschrift 78(2): 156-189.

2003-2004. Identifikacija ptičjih predstava u praistoriji. Starinar 53-54: 181-192.

Versnel H. S. 1985-1986. Apollo and Mars One Hundred Years after Roscher. Visible Religion: Annual for Religious Iconography 4-5: 134-172.

1994. Transition and Reversal in Myth and Ritual. Brill. Köln-London-New York.

Vidal-Naquet P. 1981. Recipes for Greek Adolescence. In R. L. Gordon (ed.), Myth, Religion and Society. Structuralist Essays by M. Detienne, L. Gernet, J.P. Vernant and $P$. Vidal-Naquet. Cambridge University Press. Cambridge: 163- 185.
Wachsmann S. 1998. Seagoing Ships \& Seamanship in the Bronze Age Levant. Texas A\&M University Press. College Station.

West M. L. 1990. Studies in Aeschylus. Teubner. Stuttgart. 2007. Indo-European Poetry and Myth. Oxford University Press. 0xford.

Woytowitsch E. 1978. Die Wagen der Bronze- und Frühen Eisenzeit in Italien. Prähistorische Bronzefunde 17(1). Beck. München.

Wyatt N. 2005. The Mythic Mind. Essays on Cosmology and Religion in Ugaritic and Old Testament Literature. Equinox. London. 
